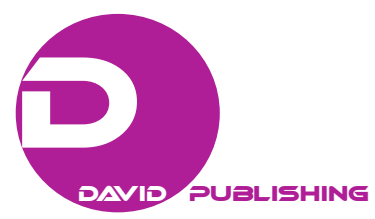

\title{
The Anti-corruption Fights: Perescoping the Whistle Blower Policy in Nigeria*
}

\author{
Joyce A. M. Ejukonemu \\ Federal College of Education (Tech), Bichi, Kano, Nigeria
}

\begin{abstract}
The 2015 elections and swearing of new leadership in Nigeria brought about new promises as well as new policies and strategies. The president elect, Muhammadu Buhari, was quick to indicate his intentions to fight corruption as one of the means through which the government intends to achieve good governance in Nigeria. This intention and follow-up action is like the biblical two-edged sword, cutting off sadness from the lower class while at the same time cutting off happiness from some corrupt people in government. The recent announcement of the whistle blower policy by the Federal Government as another means of fighting corruption in Nigeria brought about an increase in the discovery of hidden/looted money. Relying on primary and secondary findings, based on qualitative and quantitative data the paper examines the potency of the whistle blower policy on corruption. The puzzle: is the policy yielding positive result? The case provides a strong case to the methodological analysis for both institutional norms to fight corruption and good governance in Nigeria. The thrust of this paper is that, the fight against corruption is a national issue that can be successfully tackled by the citizens. The paper therefore recommends that government and its citizenry come together to fight this malice called corruption.
\end{abstract}

Keywords: corruption, whistle blower, policy and good governance

\section{Introduction}

There exists a huge gap between the wealthy and the poor in Nigeria. This gap is due to corruption. The anti-corruption fight is to remove economic distortions in order to close the gap of inequality as well as encourage development.

Economic development depends upon good policies and effective institutions to carry out these policies. The present government must have realized that in order to transform the country, institutional transformation as well as meet the aspirations of the people, especially the poor and vulnerably cannot be met without reducing if not eradicate completely the entrenched culture of corruption and impunity in the system. The paper looks at the confluence provided by the priority set by Nigeria's government to fight corruption and eliminate waste in the management of public resources and the strategies put in place.

The announcement of the whistle blower policy by the minister of finance was not just a welcome idea but a rewarding one. However, one cannot help to wonder the reasons behind the much achieved success so far. Is it that the anti-corruption fever has overtaken over the people? Or is it because of the reward attached to the

*This paper was presented at the School of Education, Federal College of Education, Kano, 19th Annual National Conference, 21-24 November 2017, Ploughoft Auditorium.

Joyce A. M. Ejukonemu, Ph.D., Department of General Studies, School of General Education, Federal College of Education (Tech), Bichi, Kano, Nigeria. 
policy? Against these backdrops, starting from the introduction this paper is sub-divided into four sections. Section two deals with conceptual underpinning. This gives us an overview on the concept of corruption. Section three highlights the consequences of corruption to the nation, institutions, and citizens. Section four deals with reform proposal which gives an insight into the strategies and policies put in place so far to fight corruption in Nigeria as well as give some recommendations.

\section{Conceptual Underpinning}

Corruption occurs where private wealth and public power overlap. Several scholars have come up with so many definitions of corruption. Ndubisi (1986), views corruption as any act by a public official which violates the accepted standards of behavior in order to serve private or public ends. It was also said to be the use of legislated power by government officials for illegitimate private gain, which leads not only to this misallocation of resources, but also affects the manner in which decisions are made (Osewe, 2012). Ackerman (2014) considered Treisman, 2007 definition as an umbrella definition quoted thus "The abuse of public power for private gain” (p. 299). Defiem (1995) defines corruption as "the side stepping of legally prescribed procedures, which regulates social action” (p. 8). These include covert behavior seen as unacceptable, various forms of embezzling public funds such as direct stealing, inflating of purchase figures or a police officer extorting bribes in the street as well as alteration and forging of documents.

There is no official or universally accepted definition of corruption. Corruption is considered as a criminal offence. The laws of Nigeria prescribe that persons accused of corrupt practices should be arraigned and prosecuted in the courts of law and if convicted, be subjected to befitting punishment (Asobie, 2012). The constitution of the Federal Republic of Nigeria provides that the "state shall abolish all corrupt practices and abuse of power" (section 15:5). Also in the (third schedule, part 1) corruption is criminalized by making it a punishable offence. Although nowhere in the constitution is the world "corruption" or "corrupt practice" specifically defined, what is captured or stated in the constitution is "gratification" and the reader is merely informed that corruption "includes bribery, fraud and other related offences" (Corrupt practices Act, 2000). However so many public officers have been peremptorily removed from office and some forced to resign from their esteemed office on account of charge of corruption. Many types of corruption and the rate of corruption are highly correlated to the extent that countries are classified as either less or more corrupt. Is poverty a cause of corruption or poverty a consequence of corruption?

\section{Consequences of Corruption}

Among close watchers and analysts of the development process in Nigeria, there is agreement that corruption is prevalent in the country and remains the major albatross on her path to growth. The consequences of corruption is said to be visible in all sectors of the economy and social sphere. These can be seen as being demonstrated by decayed infrastructure, corrupt tendencies in all the arms of government and security agencies, fraudulent practices by public office holders, the smeared international image and blurred prospects of corruption that must diminish in the near future for accelerated development to occur (Mohammed, Aluaigba, \& Kabir, 2012).

\section{Poverty and Inequality}

Looking at every sector of the society, the world at large, signs of poverty and inequality is glaring. In order to examine inequality and poverty, it is necessary to bring to notice a few methodological difficulties. The 
most common measure of poverty is household consumption or expenditure. An absolute poverty line represents the cost of some necessities, including food and other needs, such as housing, clothing, education, and health care. Rakodi (2002), Satterwaite (2004), and UN-Habibat (2006), do agree on the points that money-metric measures of poverty have limitations, which most times adversely affect comparisons of the incidence of poverty most especially in the areas of prices and patterns of consumption between the wealthy and the poor.

Access to wealth depends on the resources available to and constraints on particular households: education and skills, dependency ratios, health status, relative location of affordable residential areas and employment centres and access to public transport. The rich live well, while those who are not rich, live a life of struggle marked by poverty, ill-health and insecurity. That is to say there is an exclusion of a large proportion of residents from wealth, opportunities, and good living conditions (Varshney, 1993; Jones \& Cambridge, 2010). Inequality is said to be greater in the urban than rural areas. Economic growth is associated with urbanization and declines in the urban and rural poverty. Inequality is also seen in insecurity. Insecurity is related to vulnerability-the sensitivity of well-being to a changing environment and household's ability to respond to negative changes.

Government being a vital economic agent has done little in bringing positive economic change in Nigeria. This can be deduced by examining the situation in Nigeria. The economic performance of the nation has not been impressive for several decades meaning government interventions has not been able to cure the ills in the economy (Siyan, Adegoriola, \& Adolphus, 2016). To portray this fact Gordon 2013 examines poverty situation in Nigeria and concluded that economic growth and Sustainable Development Goals (SDG) spending has not substantially reduced poverty over the period. The key problem in operationalizing poverty is therefore defining which capacities citizens have to be considered as poor. To clarify the nature of poverty it is helpful to consider what exactly constitutes the opposite of poverty, just as the idea of "wealth" intrinsically implied a normative ideal of "successful" ones. It is difficult to conceive poverty without defining its counterpart.

Scholars have also argued that richer countries and those with high growth rates have less record of corruption and better functioning governments (Kaufmann, 2003; Aidt, 2011). In the same vein some also opined that an increase in the level of corruption from relatively clean Singapore to relatively corrupt Mexico is the equivalent of an increase in tax rate. Countries with high levels of corruption have lower levels of human development. Highly corrupt countries tend to under-invest in human capital by spending less on education, over-investing in public infrastructure relative to private investment, and degrading environmental quality. Treisman (2007) arguing from the point of poverty asserted that poverty and corruption have causal arrows that run both ways, creating vicious or virtuous spirals. However, some countries have managed to have high levels of human development in spite of the high levels of corruption. This shows that the relationship is far from deterministic Ackerman (2014).

The state of the economy has forced people to sell physical assets, move into inferior accommodation, send children out to work, reduce the quality and quantity of food consumed, postpone medical treatment, and/or withdraw from reciprocity arrangements such as rotating saving and credit associations. However, the chronic poor are unable to take advantage of the opportunities offered in cities and become trapped in a vicious circle of poverty and deprivation (Rakodi, 1999). The poverty level in Nigeria is not only high but with many socio-economic challenges (Siyan, Adegoriola, \& Adolphus, 2014). 


\section{National Threat}

Corruption is said to be driven by the dynamics of a large set of formal and informal institutions in society. Also of consideration is that neither the formal nor the informal institutions are easily changed because they constitute self-reinforcing equilibrium (Rothstein, 2007). Corruption raises transaction costs and creates uncertainty and bottlenecks in the economic. Bribery, a common type of corruption, leads to inefficient economic outcomes. It distorts sectoral priorities and technology choices by for instance, creating incentives for large defence contracts instead of rural healthcare clinics. Corruption misallocates talent to rent seeking activities and impedes long term foreign and domestic investment.

Nigeria and the West African region in the course of the 20th century was said to have gone through a revolution consisting of an explosion in population, the rise of huge cities and the rapid integration of the region into the world economy. However despite these, the country is said to be experiencing a state of absolute poverty (Siyan, Adegoriola, \& Adolphus, 2014). Nigeria is said to be bedeviled by systemic corruption is an informal institution In the case of Nigeria, lack of transparency and accountability in the management of resources in both public and private domains poses a threat to development, democracy and political stability. Toure (2012) highlighted that, the stark reality that corruption, wastage, and misappropriation of resources continue to play a significant role in undermining Nigeria's development objectives at both National and sub-national levels including the efforts to achieve the SDGs little wonder Nigeria has been ranked low on the United Nations Development Plan (UNDPs) Human Development Index (HDI).

\section{Corruption Promotes Public Revenue Loss and National Capital Flight}

The effects of corruption is said to have manifests in the lives of Nigerians in several ways thus: In their empty days, empty pockets, empty pots, empty stomach, reality of thirst, hunger and unemployment as a result the activities of these saddled with the responsibility of piloting the affairs of the ration (Osewe, 2012). Corruption, i.e. Kleptocracy is both a social practice and an ideology of the new ruling class (Akinyemi, 2010). The alarming discoveries made from the whistle blowers policy is a good point of departure.

The Finance Minister, Mrs. Kemi Adeosun, announced on behave of the federal government the approval of a whistle blowing policy to expose fraud and other related crimes in both the public and the private sectors in December 2016. Nigerians were encouraged to see the policy as timely while she urges Nigerian to report any form of violation, misconduct, or improper activity that impacts negatively on Nigerians.

The Federal government on the 24th of March 2017 disclosed that the total number of cases of fraud and illicit transactions by serving or former public officers currently investigating under its whistleblowing policy has risen to 2,251. This was confirmed in a detailed article published by Obinna Chima on Thisday exclusive story where he wrote that, more Nigerians, mostly bankers and account officers, have started to take advantage of the federal government's whistleblowing policy to report the wrongdoings of former and current public office holders suspected to have embezzled public funds and stashed them in several Nigerian banks. A breakdown of this, according to data made available by the Ministry of Finance showed that while 95 of such cases were reported using the whistleblowing website; 1,550 through a dedicated telephone line for the policy; 194 through e-mails sent by the whistleblowers; and 412 through text messages.

Furthermore, it put the number of tips received so far at 282. A breakdown of the manner in which the tips were received also showed that while 49 were through calls; 87 through SMS; 95 through the website that was developed for the initiative; and 51 through e-mails. In addition, the actionable tips received were put at 154 . 
According to the ministry, some of the tips include information about contract inflation and conversion of government assets to personal use; ghost workers; payment of unapproved funds; embezzlement of salaries of terminated personnel; improper reduction of financial penalties; and diversion of funds meant for distribution to a particular group of people (farmers).

Others include the diversion of funds to personal commercial bank accounts to earn interest; non-remittance of Pension \& National Health Insurance Deductions (NHIS) deductions; failure to implement projects for which funds have been provided; embezzlement of funds received from donor agencies; embezzlement of funds meant for payment of personnel emoluments; violation of Treasury Single Account (TSA) regulations by keeping funds in commercial banks; violation of Federal Inland Revenue Service (FIRS) Value Added Tax (VAT) regulation by adjusting VAT payment; and non-procurement of equipment required for aviation safety. Furthermore, the ministry of finance disclosed that other tips received were centered around money laundering and diversion of funds meant for approved projects; illegal sale of government assets; diversion of revenue mostly Internally Generated Revenue (IGR); financial misappropriations (embezzlement); concealed bailout funds; mismanagement of micro-finance banks; illegal recruitments; and violation of procurement Act.

THISDAY reported that some bankers were being encouraged largely by the reward of between 2.5 per cent (minimum) and five per cent (maximum) of the total amount recovered. It was gathered that several former and current public officers who had allegedly stolen from the treasury either hid the physical cash in safe houses or used shell companies, close aides, associates and family members to stash the ill-gotten funds in bank accounts. However, though the accounts are not in the names of the political office holders, they usually operate the accounts themselves, a fact that is well known by the bank account officers who help them manage the accounts.

As the federal government unveiled the whistleblowing policy as a means of recovering stolen public sector funds, a number of junior and middle-level bankers have been quietly exposing the true beneficiaries of the accounts in order to cash in on the rewards derivable from the policy. A better understanding of poverty, vulnerability, social exclusion and identification of constraints on the ability of individuals, households, and communities to access key assets and services provide pointers to appreciate policy interventions (Devas et al., 2004, cited in Rakodi, 2014).

\section{Policy Recommendation}

It is said that one major problem of statecraft and politics in Nigeria has been the inability to generate, package, and implement viable and effective public policy (Mato \& Olasupo, 2014). Another class of scholars are of the opinion that clever technical solutions, based on economic incentives are not enough to curb corruption because powerful groups with huge source of patronage will search for another vulnerably sectors to devalue. This explains why effective and long-lasting corruption control is a rare and precious achievement but most likely not beyond the power of determined and intelligent political reformers. It is recommended that, government should put structures in place that will make it difficult for officials to be involve in corruption of any form, one easy way to do this, will be to confiscate defaulters properties.

Moral leadership from top down has generated into empty rhetoric or witch hunting against opponents. It was argued that policies that will address corruption must consider the underlying conditions that create corrupt incentives, or it will have no long-lasting effects. Corruption is a symptom that state/society relations 
undermine the legitimacy of the state and lead to wasteful public policies (Glaeser \& Saks, 2006). However, where the middle class is either weak or non-existent then the task of holding government to account becomes a herculean one. The most effective policies with direct or indirect impact are national economic and social policies. Their effects are mediated through markets and through the activities of governments which have varying capacity to adopt pro-poor policies, especially at the local level (Rokadi, 2014). In the same vein Asobie (2012) highlighted that addressing corruption without tackling the underlying system of exploitation and socio-economic inequality will be treating the symptom of a deadly disease rather than exploring its epidemiology for a more enduring remedy. In other to bridge this created socio-economic inequality and exploitation, recovered wealth should be pushed into projects/programs that will benefit the less privileged for instance scholarships for orphans.

Cross-country research suggests that the gains from reducing corruption and improving governance are large. The state must protect civil liberties and establish the rule of law-rules must be clear and fair and be administered competently and fairly. These must include an honest, professional, and independent judiciary, police, and prosecutor who have similar level of integrity and competence. At the end of the day, it will yield a substantial net benefit for targeted anti-corruption intervention (Olken \& Pande 2012). The author makes bold to concur using the whistle blowers policy as one option that is already yielding clear benefits with minimal costs with not just a high rate of returns but also a promising future for the nation and her citizens. This is one policy that should not be dropped in a hurry but rather be improved upon by subsequent government.

\section{References}

Ackerman, S. R. (2014). Corruption and development. In V. Desai and R. B. Pother (Eds.), The companion to development studies (pp. 798-803). London and New York: Routledge.

Ackerman, R. S. (1999). Corruption and government. Cambridge: Cambridge University Press.

Aidt, T. (2011). Corruption and sustainability. In Ackerman and Soreide (Eds.), The international handbook on economics of corruption (Vol. 2, pp. 3-51). Cheltenham UK: Edward Elgar Publishing.

Akinyemi, B. (2010). How to combat corruption. Lecture delivered at the 10th Anniversary of the Arewa Consultative Forum, Kaduna, April, 19 (Culled from Nation Newspaper, May 4, 2010).

Defiem, M. (1995). Corruption, law and justice: A conceptual clarification. Journal of Criminal Justice, 3(23), 243-258.

Glaeser, E. L., \& Saks, R. (2006). Corruption in America. Journal of Public Economics, 90 (6-7), 1053-1073.

Gordon, D. (2013). The concept of measurement of poverty. In C. Pantozis, D. Gordon and R. Levitas (Eds.), Poverty and social exclusion in Britain. Britain: Policy Press.

Johnson, M. (2005). Syndromes of corruption: Wealth power and democracy. Cambridge: Cambridge University Press.

Jones, G. A., \& Cambridge, S. (2010). The continuing debate about urban bias: The thesis, its critics, it influence and its implication for poverty-reduction strategies. Progress in Development Studies, 19(1), 1-18.

Kaufmann, D. (2003). Rethinking governance: Empirical lessons challenge orthodoxy.Discussion draft, Washington, DC: World Bank. Retrieved from www.worldbank.org/wbi/governance/dpf/rethink-gov-standford.pdf

Mato, K. M., \& Olasupo, A. M. (2014). Political economy of public policy in Nigeria implication for sustainable development. Ibadan: Omotoso Printers.

Mohammed, H., Aluagba, M. T., \& Kabir A. (eds.). (2012). Corruption, governance and development in Nigeria: Perspectives and remedies. Nigeria: AKCDRT.

Obinna C. (2017). Nigeria FG investigating 2,251 cases through whistle blowing policy. Retrieved from https://www.thisdaylive.com/index.php/category/nigeria

Olken, B. A., \& Pande, R. (2012). Corruption in developing countries. Annual Review of Economics, 4, 479-509.

Osewe, A. M. (2012). Corruption and embezzlement in government in Africa: Reflections on the Nigerian situation. In G. Akinwumi, M. M. Adamu, and P. Ukage (Eds.), Nigeria at 50: The challenges of national building. A Publication of the Historical Society of Nigeria. 
Rakodi, C. (1999). A capital assets framework for analyzing household livelihood strategies. Development Policy Review, 17(3), 315-342.

Rakodi, C. (2002). Economic development, urbanization and poverty. In C. Rakodi and J. T. Lloyd (Eds.), Urban livelihoods: A people-centred approach to reducing poverty (pp. 23-34). London: Earthscan.

Rakodi, C. (2014). Wealth, inequality and deprivation in urban areas. In V. Desai and R. B. Pother (Eds.), The companion to development studies (pp. 438-446). London and New York: Routledge.

Rothstein, B. (2007). Anti-corruption. A Big Bang theory. Gateborg, Q o G Working Paper Series 3, May.

Siyan, P., Adegoriola A., \& Adolphus, A. (2016). Unemployment and inflation: Implication on poverty in Nigeria. Journal of Development and Society, 3(4), 17-44.

Toure, D. (2014). Foreword in corruption, governance and development in Nigeria. In A. Mohammed, M. Aluaigba, and A. Kabir (Eds.), Perspectives and remedies. Nigeria: AKCDRT.

Treisman, D. (2007). What have we learned about the causes of corruption from ten years of cross-National empirical research? Annual Review of Political Science, 10, 211-244.

Vorshney, A. (1993). Introduction! Urban bias in perspective. In A. Vorshney (Ed.), Beyond urban bias (pp. 1-22). London: Frank Cass. 